\title{
Die Suid-Afrikaanse Raad vir Natuurwetenskaplikes
}

\author{
G.S. Pool \\ Registrateur, S.A. Raad vir Natuurwetenskaplikes, Posbus 11303, Brooklyn 0011
}

Die Wet op Natuurwetenskaplikes, 1982 (Wet 55 van 1982), het op 1 Junie 1982 in werking getree en die S.A. Raad vir Natuurwetenskaplikes het op 2 September 1982 sy eerste vergadering gehou. Dit is datums wat gekom en gegaan het, maar hulle sal in die annale van die natuurwetenskaplike beroep in rooi aangeteken staan as die dae waarop gestalte gegee is aan 'n lang gekoesterde ideaal van natuurwetenskaplikes om statutêre beslag vir hul professie te verkry.

Die volgende persone is aangestel as lede en plaasvervangende lede van die Raad met ampstermyn tot 31 Augustus 1985:

\section{Lid}

Prof. S. Maske

Dr. R.R. Arndt

Prof. J.D. Skinner

Dr. D. Reitmann

Dr. B.W. Strydom

Prof. N. Grobbelaar

Prof. H.S.P. Grässer

Dr. H.S. Hofmeyr

Prof. V. Pretorius

Dr. G. Heymann

Prof. G.N. Louw

Prof. W.J. van Biljon

Prof. J.P.F. Sellschop

Dr. D.J.J. van Rensburg

Dr. C.G. Coetzee

Dr. W.L. van Wyk

Dr. R.E. Robinson

Mnr. D.L. Kyle

\section{Plaasvervanger}

Dr. C.T. Potgieter

Dr. R.O. Perry

Prof. T. Erasmus

Prof. P.H. Stoker

Dr. G.C.A. van der

Westhuizen

Prof. C.F. Cresswell

Prof. N. Sauer

Dr. J.H. Hofmeyr

Prof J.A.J. Nel

Prof. W. Gevers

Prof. A.J. Erlank

Prof. C.J.H. Schutte

Prof. M.A. Raath

Prof. D. Veldsman

Dr. H.v.H. van der Watt

Dr. D.C. Neethling

Dr. J.H.J. Coetzee

Dr. P.J. Ryan
Prof. V. Pretorius en dr. G. Heymann is onderskeidelik eenparig verkies tot President en Visepresident van die Raad.

Die Wet, as sulks, is die basiese instrument in die hande van 'n outonome Raad wat uit natuurwetenskaplikes bestaan, om 'n reeks duidelik omskrewe magte en funksies uit te voer, soos:

- die evaluasie van akademiese kwalifikasies wat vir registrasie aangebied word om te besluit of hulle aan die Raad se norme voldoen;

- die bepaling van die aard, standaard en verskeidenheid van ervaring in die beroep wat as registrasievereiste moet dien;
- die omskrywing van werk van 'n natuurwetenskaplike aard wat, vanweë hul opleiding en ervaring, slegs vir natuurwetenskaplikes voorbehou moet word;

- die omskrywing van die vereistes vir die erkenning van 'n vakkundige vereniging vir doeleindes van die Wet;

- die daarstelling van 'n professionele gedragskode vir natuurwetenskaplikes ens. ens.

Die voorgaande dui daarop dat dit vir die Raad in hoofsaak gaan om die beroep van die naturwetenskaplike en verdere bepalings in die Wet onderskryf hierdie stelling. Die bevordering van die studie en belange van ' $n$ bepaalde natuurwetenskap is die taak van die betrokke vakkundige vereniging. Die Raad word ook by implikasie betrek by veral die onderrig van die natuurwetenskapvakke en die inhoud van die leergange op beide sekondêre en tersiêre vlak. $\mathrm{Hy}$ moet noodwendig sy norm, wat akademiese kwalifikasies betref, onbevange bepaal sonder om in berekening te bring wat tans aan skole en universiteite aangebied word of kan word. Die kriterium moet allengs wees: wat is die eindproduk wat deur die samelewing vereis word en wat allerweë voldoen aan die eise gestel deur die nywerheidsektor, die navorsingsliggame, die openbare sektor en andere.

Die Raad kan egter nie sinvol oor aanvaarbare norms in die breë verband besin alvorens hy homself nie eers vergewis het van presies wat die natuurwetenskappe behels nie. Om daardie rede het hy hom dit van die begin af ten doel gestel om die natuurwetenskappe op 'n gerasionaliseerde grondslag te omskryf en dié taak sal hopelik in die afsienbare toekoms afgehandel wees. Die suiweringsproses, as dit so genoem kan word, sal hopelik enige verwarring wat tans bestaan uit die weg ruim, bymekaarbring wat bymekaar hoort en die ongesonde gekompartementaliseerde fragmentasie van spesialiteitsgebiede binne 'n bepaalde vakgebied teenwerk.

Die proliferasie van vakkundige verenigings getuig veral van laasgenoemde verskynsel. Talle van die vakkundige verenigings voer' 'n sukkelbestaan terwyl hulle, indien hulle saam onder 'n gemeenskaplike dissiplinêre saambreel sou verenig, allerweë lewensvatbaar behoort te wees. So 'n bedeling sou ook hul hand sterk wanneer hulle by die betrokke instansie sou aanklop om 'n eie tydskrif waarin navorsingstukke gepubliseer kan word. 
Dit is duidelik dat die implisiete magte van die Raad wyd strek. Dat hy hierdie magte met die nodige omsigtigheid, slegs na beraadslaging met alle belanghebbendes en sonder om inbreuk te maak op die outonomie van bestaande belange, sal uitvoer, lê voor die hand. 'n Positiewe en objektiewe benadering tot die totale problematiek van die natuurwetenskappe deur almal wat daarby betrokke is, behoort daartoe by te dra dat daar in die afsienbare toekoms op alle vlakke 'n vernuwing kan'intree tot voordeel van die land in die geheel.

Daar kan nie nagelaat word om hulde te bring aan die Gesamentlike Raad van Natuurwetenskaplike Verenigings vir sy volgehoue beywering om die Wet tot verwesenliking te bring nie. Opeenvolgende voorsitters van sy Registrasiekomitee het baie tyd en moeite opgeoffer in verband met die opstel van die betrokke wetsontwerp. Die Raad het dit goedgedink om 'n waarderingsbetuiging by wyse van sitate aan die volgende te oorhandig by geleentheid van 'n dinee gehou op 2 September 1982:

Prof. D.M. Joubert, tans Rektor van die Universiteit van Pretoria;

Dr. D. Reitmann, tans Direkteur van die Nasionale Versnellersentrum en Raadslid;

Dr. J.D. Louw, voorheen verbonde aan UKOR en tans afgetree;

Prof. V. Pretorius, tans Direkteur van die Instituut van Chromatografie en President van die Raad;

Dr. A.P. Burger, voorheen Wetenskaplike Adviseur van die Eerste Minister en tans afgetree;

Mnr. G.S. Pool, tans Registrateur van die Raad wat die G.R.N.V. met regsadvies bygestaan het.

'n Sitaat is ook oorhandig aan Sy Edele J.C. Heunis, Minister van Staatkundige Ontwikkeling en Beplanning, met wie daar oor 'n paar jaar onderhandelings gevoer is in verband met die wetgewing en wat die Wet self deur die Parlement geloods het.

Ten slotte, dit: die verwesenliking van die Wet het nie sonder teenkanting geskied nie, teenkanting wat in sekere kringe nog voortduur. Die onomstootlike feit bly egter dat die Wet op die statuutboeke staan. Die Raad het 'n moeilike opdrag om uit te voer en al sy pogings is in die finale instansie daarop gemik om die natuurwetenskaplike beroep en alles wat daarmee verband hou, dermate uit te bou dat 'n bedeling gelyk aan dié wat deur ander professies geniet word, beding kan word. Diegene wat die Wet nie goedgesind is nie, gaan onwillekeurig tog daarby baat. 'n Ernstige beroep word dus op alle natuurwetenskaplikes gedoen om hulle agter die Raad te skaar en hom te help om hulle en hul professie tot hulp te wees. 